\title{
Increasing the utilization potential of fly ashes from fluidized bed combustion by mechanical treatments
}

\begin{abstract}
The increasing use of biomasses in the production of electricity and heat delivers an increased amount burning residue, fly ash that disposal is becoming more and more restricted and expensive. Therefore, there is a great interest to utilize fly ash in other means than disposal. This study aimed to determine the suitability of air jet sieving and air classification to separate detrimental elements, such as sulfate, chloride and some heavy metals, into fine fractions. Furthermore, the effect of fly ash deagglomeration on classification selectivity was studied. Experiments were conducted using two fly ash samples originated from fluidized bed combustion of peat, forest residues and wastes. The results showed that it is possible to significantly improve the utilization potential of fly ashes using air jet classification. In classification, calcium is concentrated into a fine fraction and silica and aluminum are concentrated in coarse fractions. Sulfate, chloride and studied detrimental metals (cadmium, copper, lead and zinc) enrich to the fine fraction with high selectivity. Deagglomeration had a minor effect, as it slightly improved the classification selectivity for some elements.
\end{abstract}

Keywords: bioenergy; fractionating; grinding; processing; sieving; sustainability

\section{Introduction}

Biomass is a sustainable energy source used to produce electricity and heat. In the near future, its share will increase due to political goals, such as the EU 20-20-20 target (European Union 2009), of decreasing $\mathrm{CO}_{2}$ emissions originating from fossil fuels and increasing renewable energy use. Biomass fly ash is the residue produced from combustion of biomass in power plants, paper mills and other biomass burning facilities. In Finland, biomass, i.e., wood, bark and other forest residues, is commonly co-fired with peat, which works as a supporting fuel that evens out the fluctuation in heat capacity and ensures sufficient heat generation in cold seasons. Sometimes, minor amounts of recycled wood and recycled fuel (REF) are used as well.

Among combustion methods, fluidized bed combustion is efficient and common due to its ability to utilize low-grade fuels with fluctuating quality, composition and moisture content, or mixtures of fuels, in-situ capture of SOx and low NOx emission (Patel et al. 2017). However, the fly ash originating from fluidized bed combustion of biomasses has limited utilization potential unlike ashes from pulverized combustion of coal. Annually, 500,000 tons of fly ash originating from fluidized bed combustions of peat and wood are produced in Finland (Korpijärvi et al. 2009). Over 1.5 Mt of fly ash are produced in Europe annually (van Eijk et al. 2012), and this amount is expected to increase. The numbers evidently show that fly ash generation is a critical issue in many countries especially when considering that disposal is becoming more and more restricted and expensive, and therefore applications in which fly ashes could be utilized efficiently are in demand.

Some fly ashes can be utilized in soil improvement (Pedersen 2003), earth construction (Ohenoja et al. 2016b, a), concrete application (Rajamma et al. 2009, 2015) and as a fertilizer (Dahl et al. 2009; Ingerslev et al. 2011; Budhathoki and Väisänen 2016) if their properties comply with regulations. The regulations are country specific although international regulations exist as well. For example, the Finnish national legislation MMM 24/11 (Finnish Ministry of Agriculture and Forestry 2011), which came into effect in 2011, regulates the utilization of ash as a field or forest fertilizer and sets minimum acceptable content for $\mathrm{Ca}$, the sum of phosphorous and potassium, and maximum content for detrimental metals, as shown in Table 1. Fly ashes used in earth construction must to comply 
with Government Degree 591/2006 concerning the recovery of certain wastes in earth construction amended by Government Degree 403/2009 (Finnish Ministry of the Environment 2009). For concrete application, the European standard SFS-EN 450-1 (EN 450-1 2012) sets the maximum values for chloride and sulfate; however, it should be noted that the use of fluidized bed combustion fly ashes in concrete is not standardized in EN 450-1, which applies to ashes originating from pulverized combustion where the coal content must be over $60 \%$ or over $50 \%$ when coal combustion takes place with pure wood. However, these limit values still provide a guideline for fly ash utilization in concrete.

Table 1. Finnish limits for fly ashes to be used as a fertilizer (MMM 24/11), in earth construction (Government Degree 403/2009) and in concrete application (SFS-EN 450-1).

\begin{tabular}{|l|c|c|c|c|}
\hline & $\begin{array}{l}\text { Limit content for } \\
\text { field fertilizers }\end{array}$ & $\begin{array}{l}\text { Limit content for } \\
\text { forest fertilizers }\end{array}$ & $\begin{array}{l}\text { Limit content for earth } \\
\text { construction }\end{array}$ & $\begin{array}{l}\text { Limit content for concrete } \\
\text { application (SFS-EN 450-1) }\end{array}$ \\
\hline $\mathrm{Ca}[\%]$ & $>6$ & $>6$ & - & - \\
\hline $\mathrm{P}+\mathrm{K}[\%]$ & $>2$ & $>2$ & - & - \\
\hline $\mathrm{As}[\mathrm{mg} / \mathrm{kg}]$ & $<25$ & $<40$ & $<50$ & - \\
\hline $\mathrm{Ba}[\mathrm{mg} / \mathrm{kg}]$ & - & - & $<3000$ & - \\
\hline $\mathrm{Cd}[\mathrm{mg} / \mathrm{kg}]$ & $<2.5$ & $<25$ & $<15$ & - \\
\hline $\mathrm{Cr}[\mathrm{mg} / \mathrm{kg}]$ & $<300$ & $<300$ & $<400$ & - \\
\hline $\mathrm{Cu}[\mathrm{mg} / \mathrm{kg}]$ & $<600$ & $<700$ & $<400$ & - \\
\hline $\mathrm{Hg}[\mathrm{mg} / \mathrm{kg}]$ & $<1.0$ & $<1.0$ & - & - \\
\hline $\mathrm{Mo}[\mathrm{mg} / \mathrm{kg}]$ & - & - & $<50$ & - \\
\hline $\mathrm{Ni}[\mathrm{mg} / \mathrm{kg}]$ & $<100$ & $<150$ & - & - \\
\hline $\mathrm{Pb}[\mathrm{mg} / \mathrm{kg}]$ & $<100$ & $<150$ & $<300$ & - \\
\hline $\mathrm{V}[\mathrm{mg} / \mathrm{kg}]$ & - & - & $<400$ & $<0.1$ \\
\hline $\mathrm{Zn}[\mathrm{mg} / \mathrm{kg}]$ & $<1500$ & $<4500$ & $<2000$ & $<3.0$ \\
\hline $\mathrm{Cl}[\%]$ & - & - & - & - \\
\hline $\mathrm{SO}{ }_{3}[\%]$ & - & - & - & \\
\hline
\end{tabular}

Quite commonly, excessive content of heavy metals can prevent the use of fly ashes in the aforementioned applications. Manskinen studied the fuel composition of two different ashes and two different ash fractions (bottom and fly ash) originating from fluidized bed combustion and concluded that only bottom ash is possible to utilize as it is (Manskinen 2013). For other ash fractions, the heavy metal contents were too high. Generally, the cadmium content in fly ash produced from wood combustion is especially known to often exceed regulations (Narodoslawsky and Obernberger 1996; Pedersen 2003). Cadmium is considered the most harmful of all heavy metals because it remains in the soil, becomes enriched in food chains and is toxic to organisms (Orava et al. 2006). In addition to heavy metals, the utilization of fly ash in concrete applications is limited by chlorides and sulfates. The presence of chlorides and sulfates in cementitious materials can reduce durability through deterioration of the microstructure (Rajamma et al. 2009).

Classification or fractionation is one interesting option to improve fly ash utilization since there is a strong relationship between fly ash particle size and total heavy metal content (Davison et al. 1974; Obernberger et al. 1997; Camerani et al. 2002). An electrostatic precipitator can be used as a classifier in addition to its initial function of collecting fly ash particles from flue gases (Orava et al. 2006; Van de Velden et al. 2008; Świetlik et al. 2012). Quite often, an electrostatic precipitator consists of two or three units connected in a series. Based on the achieved results, the concentrations of detrimental metal are at their lowest in the first collector chamber and highest in the last chamber (Orava et al. 2006). However, detrimental metal content can be too high even at the first collector chamber and therefore classification afterwards is necessary. This can be done using an air classifier (Zhang et al. 2011; Lanzerstorfer 2015b, a), the centrifugal SPLITT method (Camerani et al. 2002) and sieving (Erdoğdu and Türker 1998; Chindaprasirt et al. 2004; Itskos et 
al. 2010). There is only one study (Camerani et al. 2002) concerning the classification of fly ashes from fluidized bed combustion although the results for other ashes indicate that method to be promising. For example, lead content in the coarse fraction could be reduced to $60 \%$ by separation of 20\% fines (Lanzerstorfer 2015b). Therefore, this study aimed to establish whether the utilization of fly ashes from fluidized bed combustion of peat, forest residues and wastes can be improved by mechanical classification of sulfate, chloride and some detrimental metals as well as determine the effect of fly ash deagglomeration on classification selectivity. The research was carried out at the University of Oulu in Finland during the year 2015. The regulations referred in this paper were valid in 2017 when this manuscript was written.

\section{Materials and Methods}

\subsection{Fly ashes}

Fly ashes from two different Finnish power plants were studied. Both of the power plants have bubbling fluidized bed boilers. However, the power plants use different mixtures of fuels, and therefore the fly ash samples differed in properties. Fuel composition of the first fly ash sample (FA1) was $70 \%$ forest residues and $30 \%$ peat, while in the second fly ash sample (FA2) the composition was $60 \%$ forest residues, $30 \%$ recycling waste and $10 \%$ sludge from the papermaking industry. Fly ash samples were collected from the first electrostatic precipitator unit.

The chemical composition of both fly ashes was mainly $\mathrm{CaO}$ and $\mathrm{SiO}_{2}$, but the fly ashes also contained high percentages of $\mathrm{Al}_{2} \mathrm{O}_{3}$ and $\mathrm{Fe}_{2} \mathrm{O}_{3}$ (Table 2). FA2 had a high sulfate content of $6.9 \%$. FA2 contained more detrimental elements than FA1, which is because FA2's power plant used recycling waste as fuel. Trace elements reported were cadmium $(\mathrm{Cd})$, copper $(\mathrm{Cu})$, lead $(\mathrm{Pb})$ and zinc $(\mathrm{Zn})$ since those elements were the most critical for FA1 and FA2 according to Finnish regulations (see Table 1). A huge difference between the ash samples can be seen: for FA2, Cd and $\mathrm{Zn}$ contents were four times higher, $\mathrm{Cu}$ content was 32 times higher and $\mathrm{Pb}$ content was 20 times higher compared to FA1. Both fly ashes had similar particle size: the median particle size for FA1 was $45.0 \mu \mathrm{m}$ and $46.5 \mu \mathrm{m}$ for FA2.

Table 2. Chemical and physical properties of studied fly ashes.

\begin{tabular}{|l|c|c|}
\hline & FA1 & FA2 \\
\hline Loss on ignition $950^{\circ} \mathrm{C}[\%]$ & 3.2 & 0.7 \\
\hline Particle size $\mathrm{d}_{50}[\mu \mathrm{m}]$ & 45.0 & 46.5 \\
\hline $\mathrm{CaO}[\%]$ & 16.0 & 23.0 \\
\hline $\mathrm{SiO}_{2}[\%]$ & 52.2 & 39.4 \\
\hline $\mathrm{Al}_{2} \mathrm{O}_{3}[\%]$ & 11.0 & 12.1 \\
\hline $\mathrm{Fe}_{2} \mathrm{O}_{3}[\%]$ & 4.8 & 4.9 \\
\hline $\mathrm{Na}_{2} \mathrm{O}[\%]$ & 2.1 & 2.9 \\
\hline $\mathrm{K}_{2} \mathrm{O}[\%]$ & 2.9 & 2.4 \\
\hline $\mathrm{P}_{2} \mathrm{O}_{5}[\%]$ & 1.7 & 1.3 \\
\hline $\mathrm{SO}_{3}[\%]$ & 1.7 & 6.9 \\
\hline $\mathrm{Cl}[\%]$ & 0.1 & 0.4 \\
\hline $\mathrm{Cd}[\mathrm{mg} / \mathrm{kg}]$ & 2.2 & 9.7 \\
\hline $\mathrm{Cu}[\mathrm{mg} / \mathrm{kg}]$ & 58 & 1890 \\
\hline $\mathrm{Pb}[\mathrm{mg} / \mathrm{kg}]$ & 26 & 510 \\
\hline $\mathrm{Zn}[\mathrm{mg} / \mathrm{kg}]$ & 500 & 2210 \\
\hline
\end{tabular}

\subsection{Methods}

\subsubsection{Analysis of fly ashes}


The particle size distribution of the fly ash samples reported as a volumetric median size $\left(\mathrm{d}_{50}\right)$ was measured with the laser diffraction technique (Beckman Coulter LS 13320) using the Fraunhofer model and the wet procedure using water. A specific surface area measurement was based on the physical adsorption of gas molecules on a solid surface using Micrometrics ASAP 2020, and the results were reported as BET isotherm. The main chemical components of fly ash were determined using an Omnian Pananalytics Axiosmax $4 \mathrm{kV}$ X-ray fluorescence (XRF) from a melt-fused tablet. The melt-fused tablet was produced from $1.5 \mathrm{~g}$ of fly ash melted at $1150{ }^{\circ} \mathrm{C}$ with $7.5 \mathrm{~g}$ of X-ray Flux Type 66:34 $\left(66 \% \mathrm{LiB}_{4} \mathrm{O}_{7}\right.$ and $\left.34 \% \mathrm{LiBO}_{2}\right)$. Trace elements were measured with inductively coupled plasma atomic emission spectroscopy (ICP-OES) from wet digested samples. The microwave-assisted wet digestion was performed using a 3:1 ratio of $\mathrm{HNO}_{3}$ and $\mathrm{HCl}$ acid mixture for $0.5 \mathrm{~g}$ of fly ash at $175^{\circ} \mathrm{C}$ according to EPA3051A (United States Environmental Protection Agency 2007).

\subsubsection{Low intensity grinding}

The original fly ash samples FA1 and FA2 were ground by an impact mill with one rotating and one stationary pin disc (Laboratory Fine Impact Mill 100 UPZ-II from Hosokawa Alpine, Augsburg, Germany). The aim of the grinding procedure was not to reduce median particle size but only to break down the agglomerates formed during transportation and storing due to electrostatic forces. The pin mill was operated with the lowest possible rotational speed of $2000 \mathrm{rpm}$ corresponding to a tip speed of $15 \mathrm{~m} / \mathrm{s}$ in order to achieve the deagglomeration effect on the fly ash particles. After deagglomeration, two new samples for classification were achieved: FA1_G, and FA2_G. More information about the mill type used in this study can be found in (Salman $\overline{A D}$ et al. 2007).

\subsubsection{Classification}

Two different classification methods were used to fractionate FA1 and FA2 samples into fine and coarse fractions. The first method was an air jet sieving (e200 LS) with a $20 \mu \mathrm{m}$ wire screen. Another method was using an air jet classifier (Multiprocessing System, Hosokawa Alpine, Augsburg, Germany), as presented in Fig 1. Classification rotor speed and air flow can be changed to adjust fine fraction share, and by using classification rotor speeds of 2000 and $4000 \mathrm{rpm}$ and air flows of 75 and $85 \mathrm{~m}^{3} / \mathrm{h}$, fine material shares from 6 to $45 \%$ were achieved. As an operational principle, the amount of coarse fraction increases when classifier rotor speed is increased and air flow is decreased. Parameters are still highly dependent on the material properties: particle size and shape affect classification results, and therefore each material before and after deagglomeration different classification parameters were studied. In both instances, the achieved coarse and fine fractions were collected for weighing and elemental analysis. 


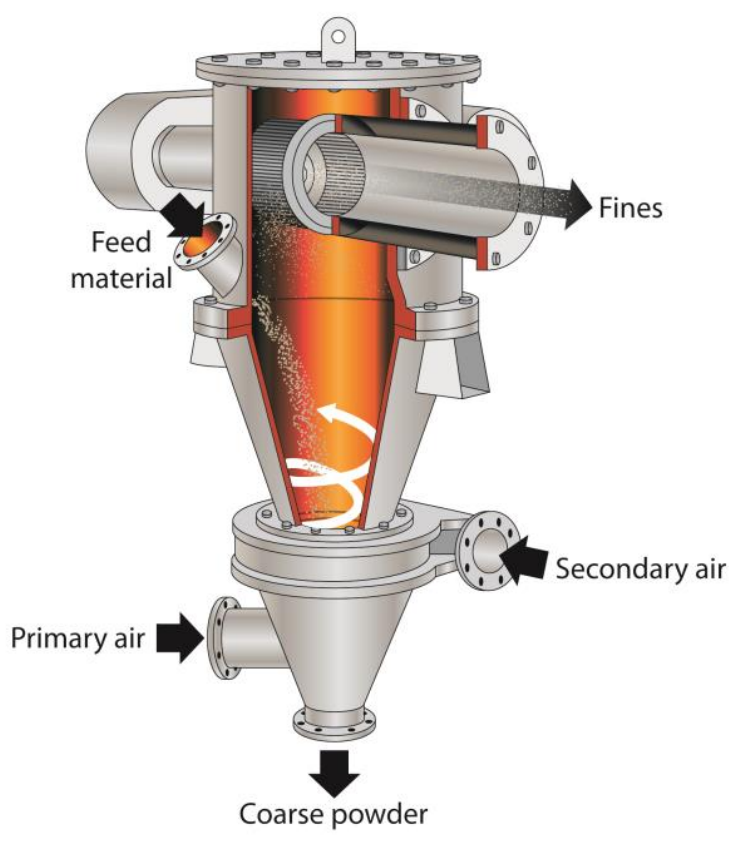

Fig 1. Classification procedure with an air jet classifier.

\subsubsection{Selectivity calculations}

Fine material share was calculated according to the general mass reject ratio:

$$
R R_{m}=\frac{m_{F i}}{m_{F}} \cdot 100,
$$

where $R R_{m}$ is fine material share [\%] and $m_{F i}$ and $m_{F}$ stand for the mass of fines and feed, respectively.

The calculation of removal efficiency was based on the following equation:

$$
E_{\mathrm{r}}=\frac{m_{\mathrm{Fi}} \cdot x_{\mathrm{Fi}}}{m_{\mathrm{F}} \cdot x_{\mathrm{F}}} \cdot 100=\left[1-\left(1-\frac{R R_{\mathrm{m}}}{100}\right) \cdot \frac{x_{\mathrm{C}}}{x_{\mathrm{F}}}\right] \cdot 100 \text {, }
$$

where $E_{r}$ is the removal efficiency of a component [\%], $x$ is content of elemental analysis and $C$ stands for coarse. The calculated removal efficiencies were plotted against the fine material share, and the selectivity curve introduced by Nelson (Nelson 1981) was fitted to them. The curve fitting was done by adjusting Nelson's selectivity index in the following equation so that the best fit was achieved:

$E_{\mathrm{r}}=\frac{R R_{\mathrm{m}} / 100}{1-Q_{\mathrm{N}}+Q_{\mathrm{N}} \cdot R R_{\mathrm{m}} / 100} \cdot 100$,

where $Q_{N}$ is Nelson's selectivity index. Representative curves can be prepared with the Nelson's selectivity index, but the selectivity index shown this way is not uniform. A positive selectivity index $\left(0<Q_{N}<1\right)$ refers to enrichment of the component to the fine, and the ideal selectivity is described as $Q_{N}=1$. In the case of a split flow, $Q_{N}=0$, the content values for coarse and fine are equal. A negative selectivity index $\left(-\infty<Q_{N}<0\right)$ is a result of component enrichment in the coarse fraction. To achieve uniform and infinite range $(0<Q<1)$ for the selectivity index, Karnis' selectivity index (Karnis 1997) was used: 
$Q_{K}=\frac{x_{1}}{x_{2}}$

where $Q_{N}$ is Karnis' selectivity index and $x_{1}$ is content of elemental analysis given for the fraction in which the content lower and $x_{2}$ is for the fraction in which the content is higher. Karnis's selectivity index has a finite range but it does not indicate in which fraction (fine or coarse) a component has been enriched. The interdependence of Nelson's and Karnis' selectivity index is:

$Q_{K}=1-\frac{1}{1-Q_{N}}$.

\section{Results and Discussion}

\subsection{Classification of main components}

Air jet classification separates components into fine and coarse fractions. According to mass balance, when some elements concentrate on a fine fraction, some elements must concentrate on a coarse fraction. Fig 2 shows the classification results for the main components, where $\mathrm{CaO}$ can be seen to concentrate in a fine fraction with a moderate selectivity $(\mathrm{Q}=0.55)$, whereas $\mathrm{SiO}_{2}$ and $\mathrm{Al}_{2} \mathrm{O}_{3}$ concentrated in a coarse fraction. Selectivity of $\mathrm{SiO}_{2}$ was 0.50 , but for $\mathrm{Al}_{2} \mathrm{O}_{3}$ the selectivity was not as clear. For FA1, there was no selectivity, and the content in fine and coarse fractions were the same, but for FA2, $\mathrm{Al}_{2} \mathrm{O}_{3}$ concentrated clearly in a coarse fraction with a selectivity of 0.5 . These results comply with those of an earlier study (Zhang et al. 2011; Ohenoja et al. 2018).

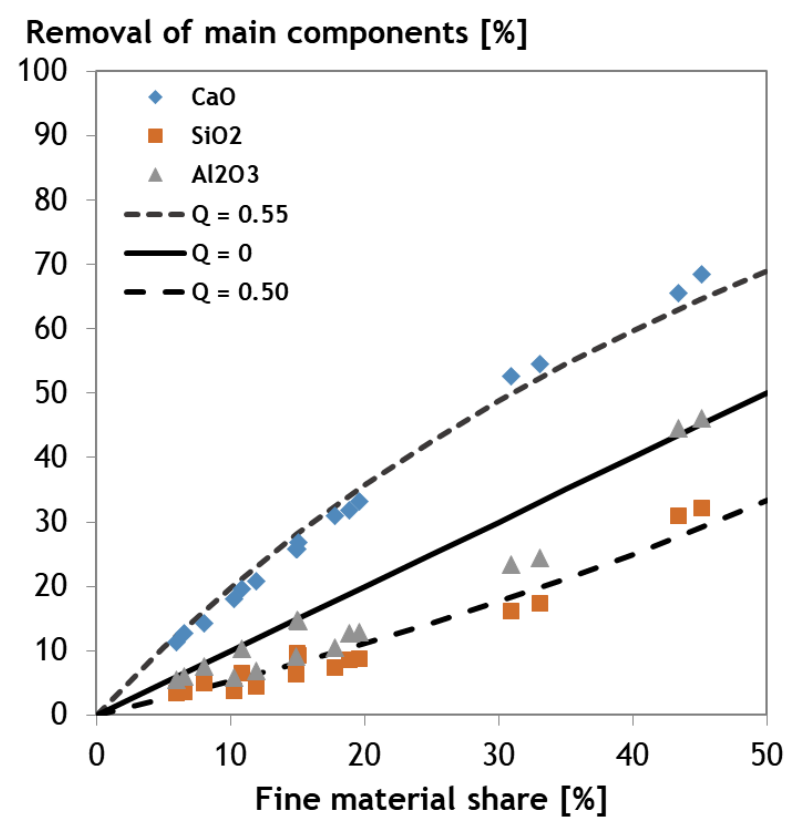

Fig 2. Fractionation of main components during fly ash classification. Flow split, i.e., when the content for fine and coarse fractions are equal, is indicated by a black line $(Q=0)$. At the upper side of this line, elements are concentrating into a fine fraction and at the underside of this line elements are concentrating into a coarse fraction.

The concentration of $\mathrm{SiO}_{2}$ and $\mathrm{Al}_{2} \mathrm{O}_{3}$ in coarse and $\mathrm{CaO}$ in fine fractions is an advantage when concerning concrete applications according to SFS-EN 450-1 (EN 450-1 2012) since the sum of 
$\mathrm{Al}+\mathrm{Si}+\mathrm{Fe}$ increases. However, for fertilizing and earth construction purposes this is a disadvantage since fertilizer should contain over $6 \%$ of $\mathrm{Ca}$, and calcium is an important component of the selfhardening reactions (Illikainen et al. 2014) used in earth construction.

\subsection{Classification of sulfate and chloride}

Classification of sulfate and chloride into fine fractions can improve utilization of coarse fractions in concrete applications, and guidelines were taken from the European standard SFS-EN 450-1 (EN 450-1 2012). In other words, chloride content must be less than $0.1 \%$ and sulfate less than $3 \%$. Typically, biomass fly ashes contain significant amounts of chloride and sulfate. It is suggested in the literature that the performance of fly ash-cement binders could be improved by the removal or control of sulfates and chlorides since the presence of these in cementitious materials can reduce durability through deterioration of the microstructure (Rajamma et al. 2009). When comparing the chemical composition of FA1 and FA2 (Table 2) to regulations (Table 1), it can be noticed that the sulfate content of FA1 is at an acceptable level but is remarkably high for FA2. The chloride content for FA1 is at the limit level and is also too high in FA2. However, these limits are only suggestions since the use of fluidized bed combustion fly ashes in concrete has not yet been standardized.

Sulfate selectivity to concentrate into a fine fraction is shown in Fig 3. In all cases, $\mathrm{SO}_{3}$ enriches into a fine fraction with a high selectivity. At lower fine material shares $(5 \%-25 \%)$, selectivity is around 0.60 , whereas at higher fine material shares $(30 \%-45 \%)$ selectivity is even higher $\mathrm{Q}=0.80$. These results comply with those of an earlier study (Ohenoja et al. 2018). Deagglomeration had a negligible effect on classification of sulfate. For FA1 the difference was within experimental limits, but for FA2 the selectivity was the same.

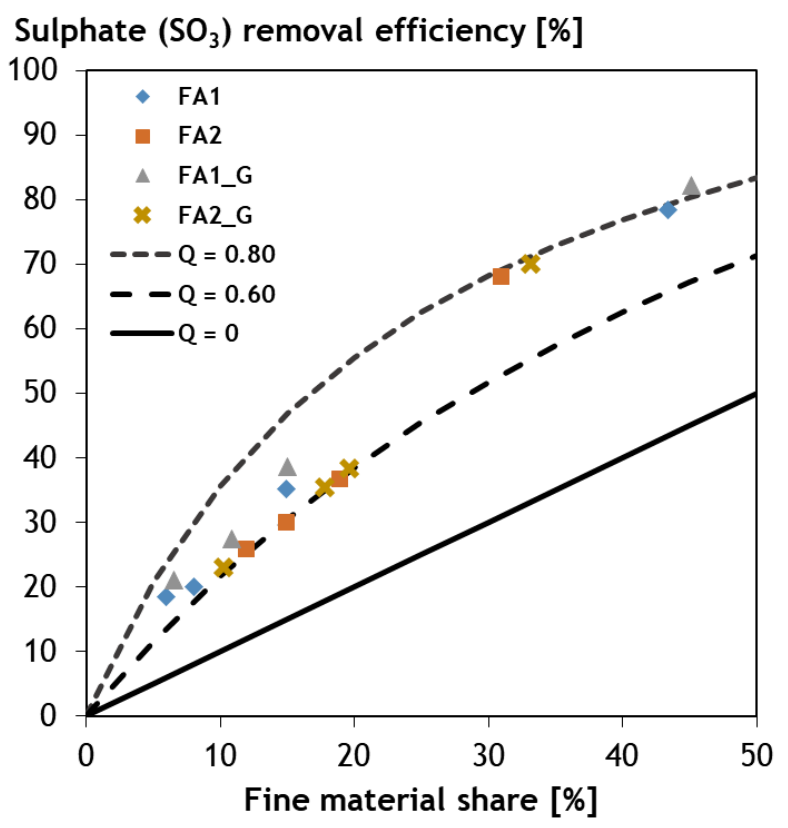

Fig 3. Fractionation of sulfate during fly ash classification. Flow split is indicated by a black line $(Q=$ 0 ), and points above this line show concentration into fine fractions.

Chloride enriches into a fine fraction with a high selectivity (Fig 4). Chloride fractionates were distinctly different between the fly ash samples: FA1 gained only a moderate selectivity of 0.45 , whereas FA2 acquired a selectivity of 0.80 . This is most probably due to the difference in initial chloride content between the ashes: FA1 had a much lower initial amount of chloride than FA2 did. 
These results comply with those of an earlier study (Ohenoja et al. 2018). Deagglomeration slightly improved the selectivity in both ashes. This refers to how chloride is most probably on the fly ash particle surfaces and therefore improved selectivity was obtained after deagglomeration.

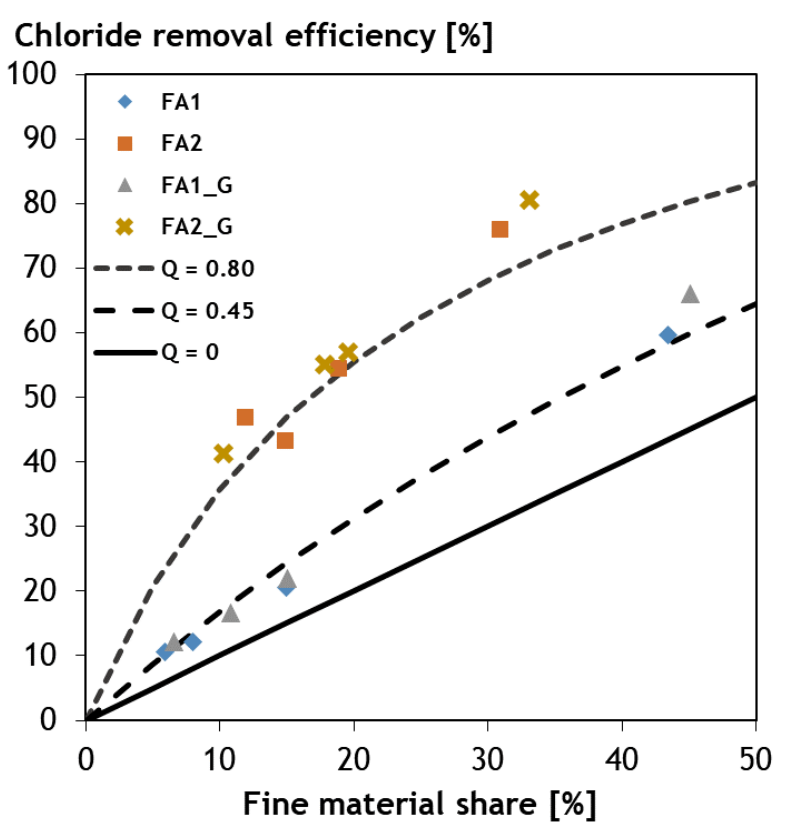

Fig 4. Fractionation of chloride during fly ash classification. Flow split is indicated by a black line $(Q=$ 0 ), and points above this line show concentration into fine fractions.

\subsection{Classification of detrimental metals}

Fly ash utilization in earth construction, soil stabilization or fertilizing is limited by regulations, which set minimum concentration values for detrimental metals, as shown in Table 1. Elements reported here include $\mathrm{Cd}, \mathrm{Cu}, \mathrm{Pb}$ and $\mathrm{Zn}$ since these elements were the most critical for the studied fly ashes according to Finnish regulations presented in Table 1. FA1 originated from combustion of peat and forest residues and can therefore be used as fertilizer. Since the contents of detrimental elements were rather low ( $\mathrm{Cd}$ is near the limit in the FA1 sample studied here), FA1 could even be used as a field fertilizer. However, since FA2 is originated partly from combustion of recycled waste, its utilization as a fertilizer is impossible (Finnish Ministry of Agriculture and Forestry 2011), but earth construction is a potential area where FA2 can be used. However, in the original FA2, copper, lead and zinc contents were higher than the limit values for earth construction.

All the detrimental metals examined in this study enriched in fine fractions. Cadmium enriched into a fine fraction with a high selectivity (Fig 5). FA1 had lower selectivity, Q=0.68, at a lower fine material share (from 5 to $20 \%$ ) and higher selectivity, $\mathrm{Q}=0.77$, at a higher fine material share (45 $\%)$. FA2 had higher selectivity, $\mathrm{Q}=0.77$, and selectivity was not influenced by fine material share. Deagglomeration slightly improved the selectivity of FA1. For both studied fly ashes, cadmium content was below earth construction $(15 \mathrm{mg} / \mathrm{kg})$ and forest fertilizer $(25 \mathrm{mg} / \mathrm{kg})$ limit. 


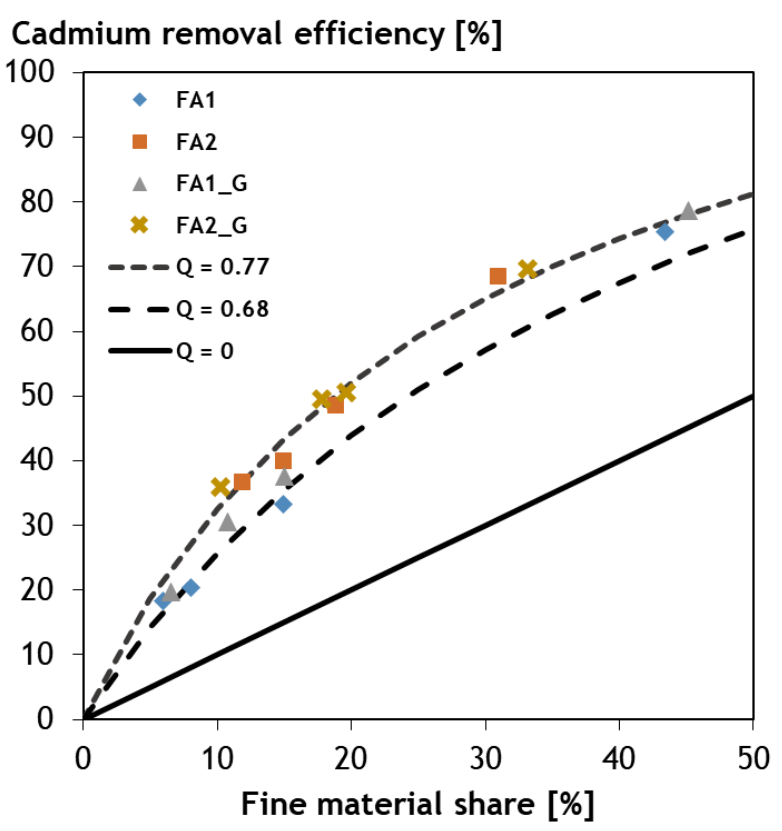

Fig 5. Fractionation of cadmium during fly ash classification. Flow split is indicated by a black line $(Q$ $=0$ ), and points above this line show concentration into fine fractions.

Copper removal efficiency was dependent on fuel type (Fig 6). In all cases, copper enriched into a fine fraction. FA1 had higher selectivity, $\mathrm{Q}=0.65$, than $\mathrm{FA} 2, \mathrm{Q}=0.35$, regardless of fine material share. Deagglomeration slightly improved the selectivity of FA2. Overall, the copper content of FA2 was a challenge: even by removing 33\% fine material, the copper content was still over the limit for earth construction ( $1620 \mathrm{mg} / \mathrm{kg}$ vs $400 \mathrm{mg} / \mathrm{kg}$ ). Therefore, one option for future study is to utilize this type of fly ash in alkali activation to stabilize heavy metals (Yliniemi et al. 2015).

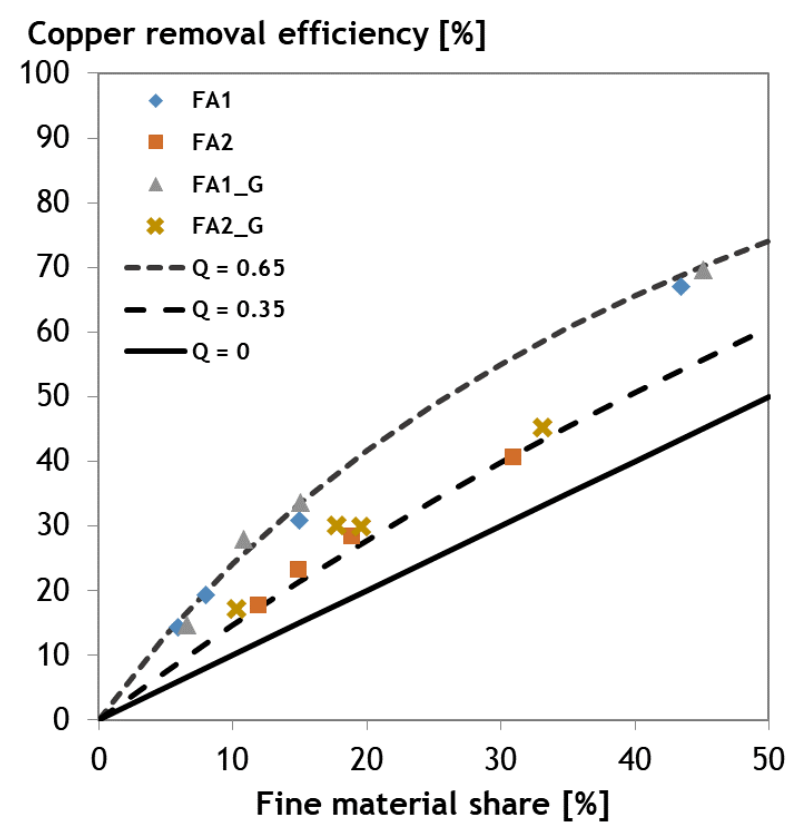

Fig 6. Fractionation of copper during fly ash classification. Flow split is indicated by a black line $(Q=$ 0), and points above this line show concentration into fine fractions.

Lead removal efficiency was good for both fuel types (Fig 7). FA1 had a lower selectivity, Q=0.67, at a lower fine material share (from 5 to $20 \%$ ) and a higher selectivity, $\mathrm{Q}=0.75$, at a higher fine material share (45\%). FA2 had a selectivity between $\mathrm{Q}=0.67$ and $\mathrm{Q}=0.75$ in all fine material shares 
studied. Deagglomeration improved the selectivity of both ashes. For FA2, by removing $30 \%$ fine material using air jet classification, lead content under the earth construction limit $(300 \mathrm{mg} / \mathrm{kg}) \mathrm{was}$ achieved. This result is in well-accordance with results of an earlier study (Lanzerstorfer 2015b).

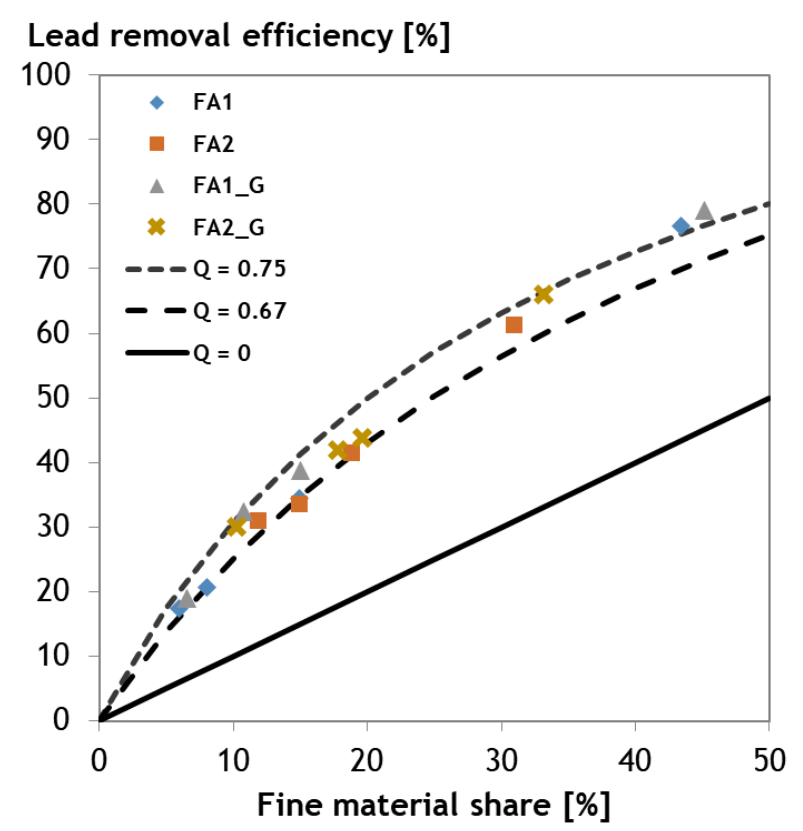

Fig 7. Fractionation of lead during fly ash classification. Flow split is indicated by a black line $(Q=0)$, and points above this line show concentration into fine fractions.

Excellent removal efficiency was also obtained for zinc (Fig 8), which enriches into a fine fraction with high selectivity. FA1 had a selectivity of $\mathrm{Q}=0.60$ in all the fine material shares studied, and deagglomeration evidently improved the selectivity at fine material shares of 8 and $18 \%$. FA2 had a selectivity between $\mathrm{Q}=0.65$ and $\mathrm{Q}=0.70$ at all studied fine material shares. Deaggmeration improved the selectivity of FA2 at a lower fine material share, but it seems that deagglomeration worsened the selectivity at high fine material shares $(30 \%)$. For FA2, by removing $10 \%$ of the fine material, a zinc content under the limit for earth construction $(2000 \mathrm{mg} / \mathrm{kg})$ can be achieved.

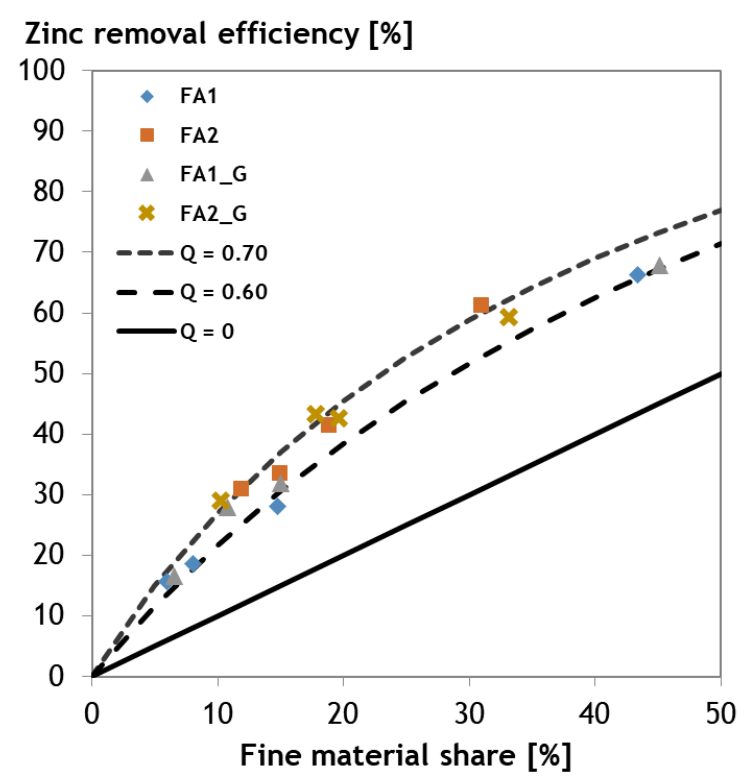

Fig 8. Fractionation of zinc during fly ash classification. Flow split is indicated by a black line $(Q=0)$, and points above this line show concentration into fine fractions. 
As shown, air jet classification is an effective method to separate detrimental elements from fly ashes originating from fluidized bed combustion with different fuel compositions. Air jet classification is especially recommended for fly ashes that will be used in earth construction and concrete applications since $\mathrm{CaO}$ concentrates into fine fractions, which is not desired in fertilizer applications. However, high calcium fly ashes may contain so much calcium that even after classification the calcium content is at acceptable level. The removal efficiency of detrimental components was studied using Nelson's and Karnis' selectivity indices, which have been used previously in screening, cleaning, fractionation and flotation studies (Nelson 1981; Karnis 1997; Hautala et al. 2009; Körkkö 2012). These are powerful tools, as they point to component removal independent of the mass reject ratio, whereas cleanliness and removal efficiency, for example, are dependent on the mass reject ratio. According to the results of this study, low intensity grinding having only a deagglomeration effect is not a necessary to improve classification selectivity since it has only minor effect to selectivity results. In the future, higher intensity grinding to reduce median particle size can be tested.

\section{Conclusions}

The studied fly ashes differed in their fuel composition, and therefore, in their chemical composition. FA2 contained much more detrimental metals, including sulfate and chloride, since it originated from a plant that uses recycling waste as $30 \%$ of its fuel. However, both ashes behaved similarly in the air jet classification process. $\mathrm{CaO}$ ended up in fine fractions and $\mathrm{SiO}_{2}$ and $\mathrm{Al}_{2} \mathrm{O}_{3}$ ended up in coarse fractions. Sulfate, chloride and the studied detrimental metals (cadmium, copper, lead and zinc) enrich into fine fractions with a high selectivity. If 30 mass- $\%$ is removed as a fine fraction from FA2, sulfate and chloride contents are under concrete limits $(<3 \%$ and $0.1 \%$, respectively) and, cadmium, lead and zinc contents are below earth construction limits $(15 \mathrm{mg} / \mathrm{kg}$, $300 \mathrm{mg} / \mathrm{kg}$ and $2000 \mathrm{mg} / \mathrm{kg}$, respectively). The content of detrimental elements in FA1 were originally low, nevertheless, it behaved accordingly to FA2 in air jet classification. Overall, the results of this study suggest it is possible to significantly improve the utilization potential of fly ashes in concrete, fertilizer and earth construction applications by using air jet classification.

\section{Acknowledgements}

This study was supported by the Finnish Funding Agency for Technology and Innovation and the following Finnish companies: Boliden Harjavalta Oy, Ekokem Palvelu Oy, Fortum Power and Heat Oy, Helen Oy, Jyväskylän Energia Oy, Kemira Chemicals Oy, Metsä Board Oyj, Napapiirin Energia ja Vesi Oy, Nordkalk Oy Ab, Paroc Group Oy, SSAB Europe Oy, Stora Enso Oyj, UPMKymmene Oyj and Valmet Technologies Oy. We would like to thank Mr. Jarno Karvonen and Mr. Jani Österlund for their contributions to the laboratory work.

\section{References}

Budhathoki R, Väisänen A (2016) Particle size based recovery of phosphorus from combined peat and wood fly ash for forest fertilization. Fuel Process Technol 146:85-89. doi: 10.1016/j.fuproc.2016.02.016

Camerani MC, Steenari B-M, Sharma R, Beckett R (2002) Cd speciation in biomass fly ash particles after size separation by centrifugal SPLITT. Fuel 81:1739-1753. doi: 10.1016/S0016-2361(02)00092-3 
Chindaprasirt P, Homwuttiwong S, Sirivivatnanon V (2004) Influence of fly ash fineness on strength, drying shrinkage and sulfate resistance of blended cement mortar. Cem Concr Res 34:1087-1092. doi: 10.1016/j.cemconres.2003.11.021

Dahl O, Nurmesniemi H, Pöykiö R, Watkins G (2009) Comparison of the characteristics of bottom ash and fly ash from a medium-size (32 MW) municipal district heating plant incinerating forest residues and peat in a fluidized-bed boiler. Fuel Process Technol 90:871-878. doi: 10.1016/j.fuproc.2009.04.013

Davison RL, Natusch DFS, Wallace JR, Evans CA (1974) Trace elements in fly ash. Dependence of concentration on particle size. Environ Sci Technol 8:1107-1113. doi: 10.1021/es60098a003

EN 450-1 (2012) SFS-EN 450-1 Fly ash for concrete. Definition, specifications and conformity criteria.

Erdoğdu K, Türker P (1998) Effects of fly ash particle size on strength of portland cement fly ash mortars. Cem Concr Res 28:1217-1222. doi: 10.1016/S0008-8846(98)00116-1

European Union (2009) Directive 2009/28. Promotion of the use of energy from renewable sources and amending and subsequently repealing

Finnish Ministry of Agriculture and Forestry (2011) Decree of the Ministry of Agriculture and Forestry on Fertiliser Products 24/11 (in Finnish)

Finnish Ministry of the Environment (2009) Government Decree amending the annexes to the Government Decree on the utilization of certain wastes in the earth construction.

Hautala J, Niinimäki J, Jokinen H, et al (2009) Screening and cleaning. In: Lönnberg, B. (Ed.), Mechanical pulping, 2nd edition. Finnish Paper Engineers' Association, Helsinki, pp 282326

Illikainen M, Tanskanen P, Kinnunen P, et al (2014) Reactivity and self-hardening of fly ash from the fluidized bed combustion of wood and peat. Fuel 135:69-75. doi: 10.1016/j.fuel.2014.06.029

Ingerslev M, Skov S, Sevel L, Pedersen LB (2011) Element budgets of forest biomass combustion and ash fertilisation - A Danish case-study. Biomass Bioenergy 35:2697-2704. doi: 10.1016/j.biombioe.2011.03.018

Itskos G, Itskos S, Koukouzas N (2010) Size fraction characterization of highly-calcareous fly ash. Fuel Process Technol 91:1558-1563. doi: 10.1016/j.fuproc.2010.06.002

Karnis A (1997) Pulp fractionation by fibre characteristics. Pap Timber 79:480-488

Körkkö M (2012) On the analysis of ink content in recycled pulps. PhD thesis, University of Oulu

Korpijärvi K, Mroueh U-M, Merta E, et al (2009) Energiantuotannon tuhkien jalostaminen maarakennuskäyttöön. VTT

Lanzerstorfer C (2015b) Air classification: Potential treatment method for optimized recycling or utilization of fine-grained air pollution control residues obtained from dry off-gas cleaning 
high-temperature processing systems. Waste Manag Res 33:1041-1044. doi: $10.1177 / 0734242 X 15597997$

Lanzerstorfer C (2015a) Investigation of the contamination of a fly ash sample during sample preparation by air classification. Int J Environ Sci Technol 12:1437-1442. doi: $10.1007 / \mathrm{s} 13762-014-0586-\mathrm{z}$

Manskinen K (2013) Utilisation aspects of ashes and green liquor dregs from an integrated semichemical pulp and board mill. PhD thesis, Aalto University

Narodoslawsky M, Obernberger I (1996) From waste to raw material - the route from biomass to wood ash for cadmium and other heavy metals. J Hazard Mater 50:157-168. doi: 10.1016/0304-3894(96)01785-2

Nelson G (1981) The screening quotient: a better index for screening performance. Tappi 64:133134

Obernberger I, Biedermann F, Widmann W, Riedl R (1997) Concentrations of inorganic elements in biomass fuels and recovery in the different ash fractions. Biomass Bioenergy 12:211-224. doi: 10.1016/S0961-9534(96)00051-7

Ohenoja K, Körkkö M, Wigren V, et al (2018) Fly ash classification efficiency of electrostatic precipitators in fluidized bed combustion of peat, wood, and forest residues. J Environ Manage 206:607-614. doi: 10.1016/j.jenvman.2017.10.047

Ohenoja K, Tanskanen P, Peltosaari O, et al (2016a) Effect of particle size distribution on the selfhardening property of biomass-peat fly ash from a bubbling fluidized bed combustion. Fuel Process Technol 148:60-66. doi: 10.1016/j.fuproc.2016.02.023

Ohenoja K, Tanskanen P, Wigren V, et al (2016b) Self-hardening of fly ashes from a bubbling fluidized bed combustion of peat, forest industry residuals, and wastes. Fuel. doi: 10.1016/j.fuel.2015.10.093

Orava H, Nordman T, Kuopanportti H (2006) Increase the utilisation of fly ash with electrostatic precipitation. Miner Eng 19:1596-1602. doi: 10.1016/j.mineng.2006.07.002

Patel A, Basu P, Acharya B (2017) An investigation into partial capture of CO2 released from a large coal/petcoke fired circulating fluidized bed boiler with limestone injection using its fly and bottom ash. J Environ Chem Eng 5:667-678. doi: 10.1016/j.jece.2016.12.047

Pedersen AJ (2003) Characterization and electrodialytic treatment of wood combustion fly ash for the removal of cadmium. Biomass Bioenergy 25:447-458. doi: 10.1016/S09619534(03)00051-5

Rajamma R, Ball R, Tarelho L, et al (2009) Characterisation and use of biomass fly ash in cementbased materials. J Hazard Mater 172:1049-1060

Rajamma R, Senff L, Ribeiro MJ, et al (2015) Biomass fly ash effect on fresh and hardened state properties of cement based materials. Compos Part B Eng 77:1-9. doi: 10.1016/j.compositesb.2015.03.019 
Salman AD, Ghadiri M, Hounslow MJ (2007) Handbook of Powder Technology Vol. 12 Particle Breakage. Elsevier, The Netherlands

Świetlik R, Trojanowska M, Jóźwiak MA (2012) Evaluation of the distribution of heavy metals and their chemical forms in ESP-fractions of fly ash. Fuel Process Technol 95:109-118. doi: 10.1016/j.fuproc.2011.11.019

United States Environmental Protection Agency (2007) Method 3051A: Microwave Assisted Acid Digestion of Sediments, Sludges, Soils, and Oils, part of Test Methods for Evaluating Solid Waste, Physical/Chemical Methods. https://www.epa.gov/sites/production/files/201512/documents/3051a.pdf. Accessed 19 Dec 2016

Van de Velden M, Dewil R, Baeyens J, et al (2008) The distribution of heavy metals during fluidized bed combustion of sludge (FBSC). J Hazard Mater 151:96-102. doi: 10.1016/j.jhazmat.2007.05.056

van Eijk RJ, Obernberger I, Supancic K (2012) Options for increased utilization of ash from biomass combustion and co-firing. IEA Bioenergy Task 32, Arnhem

Yliniemi J, Pesonen J, Tiainen M, Illikainen M (2015) Alkali activation of recovered fuel-biofuel fly ash from fluidised-bed combustion: Stabilisation/solidification of heavy metals. Waste Manag 43:273-282. doi: 10.1016/j.wasman.2015.05.019

Zhang T-S, Yu Q-J, Wei J-X, Zhang P-P (2011) Effect of size fraction on composition and pozzolanic activity of high calcium fly ash. Adv Cem Res 23:299-307. doi:

10.1680/adcr.2011.23.6.299 